\title{
Loss Recovery for Entrepreneurs Re-Entering from Business Failure
}

\author{
Munjiati Munawaroh ${ }^{1, *}$ Ika Nurul Qamari $^{1}$ \\ ${ }^{1}$ Universitas Muhammadiyah Yogyakarta, Indonesia \\ *Corresponding author. Email: munjiatim@umy.ac.id
}

\begin{abstract}
The purpose of this study is to identify the entrepreneurial failure impacts and how the process of recovering from losses caused by business failure to re-enter the next business. The research data were obtained using six case studies on companies that re-entered from failure. This business failure caused economic, social, and psychological costs. A failed entrepreneur needs recovery from losses that consist of economic, social, and psychological losses. The interview results with entrepreneurs uncovered that economic recovery from business failures was through family support and loans, bank loans, gifts from friends, and working as employees in other businesses. Meanwhile, the social impact recovery process was by establishing new relationships with other suppliers by instilling trust. Besides, support from family and friends was the psychological recovery. Religiously, recovery from business failure was done with more worship and giving alms.
\end{abstract}

Keywords: Recovery, Business Failure, Economic, Social, Psychological.

\section{INTRODUCTION}

Business failure is one aspect of entrepreneurship. Business failure causes financial loss [1], emotional distress [2-5], and social loss [6]. Singh, Corner, \& Pavlovich's [7] research found that business failure would impact the economic, social, psychological, and physiological life of entrepreneurs.

Business failure's economic impact is the financial loss caused by business costs that exceed business income and cannot attract new debt or equity funding [4]. Being shunned by friends and family, losing credibility due to business failures, and having a negative stigma towards business failure are the social effects of failure [8]. Meanwhile, business failure's psychological impacts are emotional stress in the form of sadness [4] and trauma $[2,4]$.

Entrepreneurs who experience business failure need recovery from their grief [4] and financial and social recovery. The research revealed that business failure's financial costs could be resolved by selling assets or borrowing money from friends [7]. Telling others about failures, seeking support through social networks, or finding new networks are social recovery from business failure [8].
Meanwhile, psychological cost recovery can be accomplished with an orientation toward loss and improvement [4]. Loss orientation changes the interpretation of events so that individuals can regulate their emotions [4] and resolve emotions associated with failure [9]. Besides, looking for friends, family, and psychologists to talk about sadness is the orientation toward loss. Furthermore, improvement orientation is to remove feelings of loss [9]. Avoiding sources of stress resulting from business failure while being constructive is a way of orientation towards change. An example of improvement presentation is by seeking new business [4].

Previous research analyzed recovery from organizational failures occurring in various countries. Shepherd [4] carried out research in the United States, Cope [2] conducted a study in the United Kingdom and the United States, and Singh, Corner \& Pavlovich [7] conducted research in New Zealand. In contrast to previous studies, this study wants to know how to recover from a business failure in entrepreneurs in a country where the population adheres to religion, and the majority of the population is Muslim, such as Indonesia. It is essential to recover from business failure using a religious approach because religion can play a crucial general role in the problem-solving process [10]. Research by Pargament et al. [10] revealed that religion 
could overcome problems arising from previously experienced negative events.

\section{LITERATURE REVIEW}

\section{Failure Definition}

Experts have not yet accepted the concept of business failure [11-13]. According to some scholars, there are multiple concepts of business failure. The definitions include business closure [14-16] and business termination [14,17-19]. Another meaning of business failure is a situation under which income drops so that costs exceed income [4,5,14,20]; there are deviations from expectations $[6,7,14,18,21-23]$.

There are two perspectives on the meaning of business failure. Based on several definitions of business failure put forward by several experts, there are two groups of meanings: business closure and deviations from the expected results. All of these viewpoints for default meanings are subject to deviation from the expected results because deviations from expectations mean business closures and deviations from expectations, but the business can still operate [24]. This study examines business failures due to poor performance in the form of business closures.

\section{Failure Cost}

Entrepreneurs who experience failure will bear financial costs, social costs, and psychological costs [6].

\section{Financial Costs}

Financial costs are costs incurred due to business failure [1]. Failure causes financial loss because, in this case, business expenses are higher than operating income [25]. Costs that arise because of a fall in income and increased costs are just as significant and cannot attract new debt or equity funding [4]. Consequently, insufficient funds are used to continue the business [32].

\section{Social Cost}

Social costs are costs associated with the failure effects on personal and professional relationships [7,8]. Social costs may be in the form of relationship injury, loss or shunning by friends or family, loss of reputation due to company failure, and negative stigma of business failure $[7,8]$.

\section{Psychological Costs}

Negative emotions arising from disappointment are psychological costs [8]. Losing business can trigger a negative emotional response. Jenkin, Wiklund, and Brundin [26] have examined the extent to which entrepreneurs felt sad after company failures and why entrepreneurs could react differently to their business failures. Their research results disclosed that the sadness level felt by struggling entrepreneurs varied. Under the same circumstances of failure, the disappointment felt by entrepreneurs who had encountered failure previously was less than those felt by entrepreneurs who had never experienced failure before. If the costs of failure were too high compared to the benefits of learning from failure, entrepreneurs could choose to leave their business careers [6].

\section{Failure Recovery}

\section{Financial recovery}

Financial recovery overcomes the economic consequences of failure [8]. Based on qualitative research conducted by Singh et al. [7], selling their assets to pay off business debts and borrowing money from friends or families are ways of financial recovery.

\section{Social recovery}

Social recovery is social assistance in addressing problems, such as losing friends, falling reputation, and family conflicts [7]. Some social recoveries are telling others about failures, seeking support through social networks, or finding new networks to support failures [8].

\section{Psychological recovery}

Psychological recovery can be done by focusing the thoughts so that business failure does not trigger negative emotions [7]. Shepherd [4] split psychological recovery into two cases: the loss of orientation and improving orientation. Loss orientation changes the perception of events so that individuals regulate their emotions [4] and overcome the emotions associated with disappointment [9] not to become negative emotions. A loss orientation may be achieved, e.g., by informing sadness/grief to other people, such as family, friends, and counselors. Improving orientation is to eliminate loss feelings [9] by reducing the stress emerging from company failure and being constructive, such as seeking new businesses [4].

Apart from the loss of orientation and improving orientation approaches, psychological recovery can be achieved using a religious approach. Pargament et al. [10] explained that religion plays a significant general role in the problem-solving process. Research results from Pargament et al. [27] indicated that religion could overcome problems arising from previously experienced negative events. Business failure is one of the negative events experienced by entrepreneurs, so that psychological damage recovery can be achieved with a religious approach. This psychological recovery is, therefore, grouped into religious and non-religious recovery. Religious recovery is to solve problems emerging from previous negative events [27].

\section{METHODS}

This analysis used a qualitative research method based on six case studies. Demonstrating rigor with 
deliberate and thorough data analysis articulation is critical in enhancing the robustness of qualitative entrepreneurship research [2]. Figure 1 shows the analysis data components, according to Miles [28]. The data analysis elements in qualitative research, especially in case studies, are iterative, starting from data collection, data display, data reduction, and drawing conclusions and verification, as shown in Figure 1 [28].

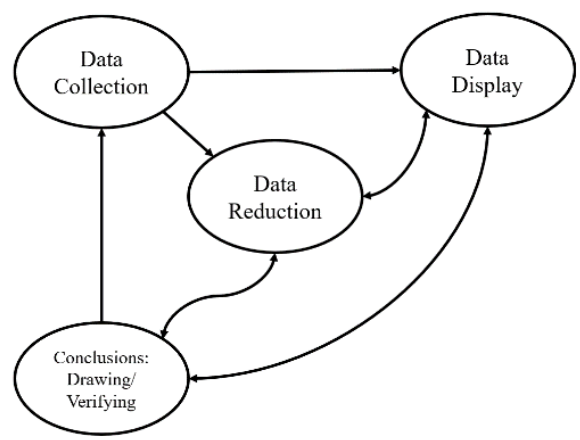

Figure 1. Data Analysis Components

Source: Miles [28]

\section{Data Collection}

Data collection was carried out by observations and semi-structured interviews with entrepreneurs who had experienced business failures and were currently running their next business. Notes were made before, during, and after the interview by creating an interview protocol to guide semi-structured interviews with open and tentative questions to determine the topic's sensitivity. The use of the interview protocol in case studies increases reliability [29].

During the interview, the researchers allowed the respondents to say things based on previously planned topic-guide questions. The interview process would take place for about half to two hours in early 2020. The interviews were recorded and processed using NVivo software. The case study involved six businesses in Yogyakarta, Indonesia.

The informants in this study were the owners or managers who experienced failure. In the data triangulation, this study used informants' friends who knew when the business failure occurred. The researchers interviewed the informants, took notes, and recorded the interview. Researchers then processed data using NVivo software and performed analyzes to find research lines and develop theories about the recovery process from business failure.

\section{Data Display}

Data display can be performed simultaneously with data collection or after data collection. Data display is a collection of organized and compressed information in a brief manner, which enables conclusions to be drawn [28]. This study's data display was systematically and robustly organized to describe and explore what, why, and how business failures occurred. Descriptions make complex things easier to understand by reducing unnecessary component items, whereas exploration can take the form of confirming existing theories. Data display can be in the form of matrices, graphs, maps, and networks, where the researcher determines which data to be included in the study [28].

\section{Data Reduction}

In this study, data reduction involved selecting, focusing, simplifying, abstracting, and transforming data that appeared in field notes or written transcriptions. The researchers determined which conceptual framework, which cases, which research questions, and which data collection approach to choose [28]. Thus, data reduction was to separate relevant data from irrelevant ones, adjusted to the research objectives. Data reduction was made by coding/labeling.

Encoding the data was carried out by categories that were critical points for the entrepreneurs in each case. Not all the interview data could be used as a study, but this work required coding a critical part of the data collection results.

\section{Drawing Conclusion}

Data presentation and data reduction are tools for conducting an analysis. In qualitative research, data presentation, data reduction, and drawing conclusions are carried out in parallel. The researchers made comparisons in six cases to identify similarities and distinctions in one case and another, analyzed between cases to generate insights from the data, and made judgments.

\section{RESULTS AND DISCUSSION}

This study used six cases of companies that had experienced failure. Based on data collection, data display, and data reduction, the discussion was divided into three sub-sections in this section. Sub-section 2.5.1 discusses the description of six cases included in the study, subsection 2.5.2 about aspects of life affected by the business failure, and subsection 2.5.2 regarding loss recovery for entrepreneurs re-entering from business failures. 


\section{The Description of Six Cases Included in the Study}

Table 1 describes six case studies of companies with failure experiences and informants who were business owners and business managers.

\section{Aspects of Life Affected by Business Failure}

Table 2 shows the three aspects of life affected by business failure. The columns in the table reflect the three aspects of entrepreneurs' life that could be affected by a business failure: economic, social, and psychological.

Table 1. The Description of Six Cases Included in the Study

\begin{tabular}{|c|c|c|c|c|c|}
\hline Case & Age/sex & Failure experience in entrepreneurial venture & $\begin{array}{l}\text { Length of business } \\
\text { experience }\end{array}$ & $\begin{array}{l}\text { Current } \\
\text { business }\end{array}$ & $\begin{array}{l}\text { Current } \\
\text { business age }\end{array}$ \\
\hline $\mathrm{A}$ & Female/35 & $\begin{array}{l}\text { production and sale of headscarves, Aceh food } \\
\text { restaurants, production and sale of children's } \\
\text { clothing, Hajj equipment }\end{array}$ & 21 years & $\begin{array}{c}\text { Hajj } \\
\text { equipment }\end{array}$ & 21 years \\
\hline B & Female/46 & $\begin{array}{l}\text { sewing services, producing t-shirts and making bed } \\
\text { linen, ties, and bakery resellers }\end{array}$ & 15 years & $\begin{array}{l}\text { tie and } \\
\text { bakery } \\
\text { reseller }\end{array}$ & eight years \\
\hline $\mathrm{C}$ & Male/38 & $\begin{array}{l}\text { selling artist photo, assembling computers, selling } \\
\text { software, e-commerce English training, social } \\
\text { media operator, car wash and car salon franchise, } \\
\text { and sharia branding }\end{array}$ & 25 years & franchise & 12 years \\
\hline $\mathrm{D}$ & Male/37 & $\begin{array}{l}\text { selling bags and accessories, red ginger distributor, } \\
\text { bakery, scrap metal business, sand miner, bakery, } \\
\text { and catering }\end{array}$ & 11 years & $\begin{array}{l}\text { bakery } \\
\text { and } \\
\text { catering }\end{array}$ & three years \\
\hline $\mathrm{E}$ & Male/51 & motorbike broker, chili eel, shoe laundry & 23 years & $\begin{array}{l}\text { shoe } \\
\text { laundry }\end{array}$ & five months \\
\hline $\mathrm{F}$ & Female/46 & selling snacks, batik, and fashion designers & 13 years & batik & ten years \\
\hline
\end{tabular}

In this study, the entrepreneurs who were informants consisted of three men and three women. The entrepreneurs' age ranged from 37 to 51 years and had 11 to 25 years of business experience. Entrepreneurs in this study who became informants had experience in closing businesses and changing business areas.

Westhead et al. [30] elucidated three types of entrepreneurs: a novice entrepreneur, serial entrepreneur, and portfolio entrepreneur. A novice entrepreneur is an entrepreneur with no prior private business ownership experience but currently owns a minority or majority equity stake in an independent business. A serial entrepreneur is a person who has sold/closed a company in which he/she had a minority or majority ownership stake before and now owns a minority or majority ownership stake in a single independent business. Meanwhile, a portfolio entrepreneur can be viewed as a person who currently has a minority or majority ownership interest in two or more independent companies that are younger, purchased, and/or inherited by them.

The informants in this case study were all combinations of serial entrepreneurs and portfolio entrepreneurs. They had other businesses when one of them closed. Likewise, when they opened a new business, they were still running other businesses. The business that was currently running ranged from five months to 21 years.
Table 2 offers explanations of how business failure impacted all three aspects of life, thereby illustrating the impact of these losses on entrepreneurs' lives. Three of the six entrepreneurs who reported an economic loss from business failure increased bank debt or had a lot of bank debt. Even debt collectors were after two out of three business people who had bank debt. In some economic losses, two out of six entrepreneurs run out of capital due to failed businesses. In the findings reported in Table 2 regarding the impact on social aspects of entrepreneurs' lives, four out of six entrepreneurs had no social implications. One of six entrepreneurs reduced supplier confidence, and one of six entrepreneurs was shunned because of friends and family conflicts. Further, the entrepreneurs described the psychological effects of venture failure. Three out of six entrepreneurs felt sad because of it. Two of the six entrepreneurs suffered from depression, one of six entrepreneurs got emotional, and one of six entrepreneurs had a phobia when debt collectors demanded the debt. 
Table 2. Three Aspects of Life Affected by Business Failure

\begin{tabular}{|c|l|l|l|}
\hline Case & \multicolumn{1}{|c|}{ Economic } & \multicolumn{1}{|c|}{ Social } & \multicolumn{1}{|c|}{ Psychological } \\
\hline A & Debt increases. & No social effect & Feeling grief \\
\hline B & $\begin{array}{l}\text { The capital runs out, and the account } \\
\text { payables are difficult to pay off }\end{array}$ & $\begin{array}{l}\text { Reduced supplier } \\
\text { confidence }\end{array}$ & $\begin{array}{l}\text { Feeling down, hopeless, and almost } \\
\text { giving up }\end{array}$ \\
\hline C & $\begin{array}{l}\text { Has a lot of bank debt, and creditors are } \\
\text { looking for him/her to collect the debt }\end{array}$ & No social effect & $\begin{array}{l}\text { Gets emotional when creditors are } \\
\text { looking for him/her to collect the debt }\end{array}$ \\
\hline D & $\begin{array}{l}\text { No income, a lot of bank debt, and } \\
\text { creditors are looking for him/her to } \\
\text { collect money }\end{array}$ & $\begin{array}{l}\text { Shunned due to friends } \\
\text { and family conflicts }\end{array}$ & $\begin{array}{l}\text { The entrepreneur feels down, becomes } \\
\text { dazed, has phobia when debt collectors } \\
\text { demands debts, and is afraid every time } \\
\text { a call comes in. }\end{array}$ \\
\hline E & No income & No social effect & $\begin{array}{l}\text { Entrepreneur feels grief but only } \\
\text { temporarily. }\end{array}$ \\
\hline F & Capital runs out. & No social effect & Entrepreneur feels grief and confused. \\
\hline
\end{tabular}

These findings confirm and corroborate Shepherd et al. [5], Shepherd et al. [1], Ucbasaran et al. [6], and Singh et al. [7] studies. Shepherd et al. [5] studied negative emotional reactions to project failure. Shepherd et al. [1] investigated the balance of the financial and emotional costs of business failure. Ucbasaran et al. [6] examined the processes and consequences of business failure for entrepreneurs. Consequences of business failure in Ucbasaran et al. [6] research are financial, social, psychological, and inter-relationship from financial, social, psychological. Besides, Singh et al. [7] explored how entrepreneurs experienced failure, how they coped with it, and how coping strategies influenced what entrepreneurs learned from failure. Research findings from Singh et al. [7] about the economic impacts were that the entrepreneur was unemployed after the venture failure, creditors called them for money, and no income. The psychological impacts of business failure were depression, anger, guilt, and even phobia development. The social impacts of business failure included a distance from friends, and the marriage ended in the middle of venture failure. On the social aspect, this study's results are different from Sing. In this study, most entrepreneurs did not experience any social impact. Based on interviews with informants, their business activities were not much directly influenced by social society. However, most of this research's findings regarding business failure's impact are not far from previous studies' results.

Table 3. Quotes regarding Aspects of Life Affected by Business Failure

\begin{tabular}{|c|c|c|}
\hline $\begin{array}{l}\text { Aspects of } \\
\text { Failure }\end{array}$ & Emerging themes & Example of supportive quotes \\
\hline Economy & Financial Pressure & $\begin{array}{l}. . \text { I do not work and have no income .. } \\
\ldots \text { the house was sold... I did not have a vehicle... }\end{array}$ \\
\hline Social & $\begin{array}{l}\text { Trust from suppliers goes } \\
\text { down } \\
\text { Shunned by friends } \\
\text { The relationship with the } \\
\text { partner is disturbed }\end{array}$ & $\begin{array}{l}\text {... "I could not cover my debt, in the end, I could not take } \\
\text { anything anymore"... "they did not believe anymore..." } \\
\ldots \text { I have so many friends, so I cannot see them when I } \\
\text { fall. Even though we still have friends, huh... My condition is ... } \\
\text { suddenly disappear. In the past, the purpose of friendship was } \\
\text { because of money. } \\
\text { We fought a lot ... }\end{array}$ \\
\hline Psychology & Phobias with a debt collector & $\begin{array}{l}\text {... I feel down, almost giving up, there is also despair } \\
\ldots \text { ee ... there is feeling sad, but it is not sustainable ... } \\
\text { So dazed... I sometimes ride a motorbike around, and I do not } \\
\text { know where I am going ... } \\
\ldots \text { when being chased by debt collectors, I went into hiding...... if } \\
\text { there are incoming calls, we first paranoid of it ... even though, it } \\
\text { was my parents who called me ... when a phone rings, it feels } \\
\text { chaotic... }\end{array}$ \\
\hline
\end{tabular}


Table 3 displays quotes regarding aspects of life affected by business failure.

\section{Loss Recovery for Entrepreneurs Re-entering from Business Failure}

Table 4 presents the losses' recovery for entrepreneurs re-entering from business failures. The columns in the table demonstrate the three aspects of the losses' recovery for entrepreneurs re-entering from business failures: economic, social, and physiological from non-religious and psychological religious viewpoints.

In economic factors, two of the six ways of recovery from business loss were work in other institutions as a source of income and paying debts due to failed took loans to banks to recover the effects of economic failures.

In the findings reported in Table 4 regarding the impact on the social aspects of life, four of six entrepreneurs had no social recovery because there was no social impact from business failure. One of six entrepreneurs recovered from the reduced supplier confidence by paying debts to suppliers in installments for better relationships with suppliers. Besides, one of six entrepreneurs, who was shunned by friends, recovered by improving relations with his wife and choosing pious friends.

Furthermore, entrepreneurs described psychological effects due to venture failure. Recovery from sad because of business failure was done with getting support from

Table 4. Losses' Recovery for Entrepreneurs Re-entering from Business Failures

\begin{tabular}{|c|c|c|c|c|}
\hline Case & Economic & Social & $\begin{array}{l}\text { Psychological Non- } \\
\text { religious }\end{array}$ & Psychological Religious \\
\hline $\mathrm{A}$ & $\begin{array}{l}\text { A family loan of } 400 \\
\text { million for three months } \\
\text { was made to reduce bank } \\
\text { interest, but the bank debt } \\
\text { was still running. }\end{array}$ & $\begin{array}{l}\text { No social } \\
\text { recovery }\end{array}$ & Support from husband & $\begin{array}{l}\text { Entrepreneurs kept praying and } \\
\text { gave alms a lot. In terms of } \\
\text { worship, the quantity and quality } \\
\text { were still fluctuating. } \\
\text { Entrepreneurs thought positively } \\
\text { and considered the failure they } \\
\text { experienced a trial from God. } \\
\text { She went for Hajj so that the } \\
\text { sadness soon diminished. }\end{array}$ \\
\hline $\mathrm{B}$ & $\begin{array}{l}\text { Work as an employee in } \\
\text { an educational institution } \\
\text { and collect salaries to pay } \\
\text { off debts, cancel debt from } \\
\text { suppliers, and get } \\
\text { government loans with } \\
\text { low interest }\end{array}$ & $\begin{array}{l}\text { Entrepreneurs } \\
\text { paid debts to } \\
\text { suppliers in } \\
\text { installments so } \\
\text { that relationships } \\
\text { with suppliers } \\
\text { could be better. } \\
\end{array}$ & $\begin{array}{l}\text { Entrepreneur shared } \\
\text { stories with friends. } \\
\text { The friends' } \\
\text { encouragement and } \\
\text { socialization was } \\
\text { inspiring. }\end{array}$ & $\begin{array}{l}\text { The religious side of his } \\
\text { recovery was being closer to } \\
\text { Allah, more devoted to prayer. } \\
\text { The quantity of pray was } \\
\text { constant but more serious. }\end{array}$ \\
\hline $\mathrm{C}$ & $\begin{array}{l}\text { The entrepreneur planned } \\
\text { his next business when he } \\
\text { saw that the business was } \\
\text { going to close. }\end{array}$ & $\begin{array}{l}\text { No social } \\
\text { recovery }\end{array}$ & $\begin{array}{l}\text { No psychological } \\
\text { non-religious } \\
\text { recovery }\end{array}$ & $\begin{array}{l}\text { Learning the love of Allah, the } \\
\text { love of the apostle Muhammad, } \\
\text { and understanding the justice of } \\
\text { God }\end{array}$ \\
\hline $\mathrm{D}$ & $\begin{array}{l}\text { The other party helped the } \\
\text { businessman pays off all } \\
\text { bank loans and provided } \\
\text { freedom in paying } \\
\text { installments. }\end{array}$ & $\begin{array}{l}\text { Improving } \\
\text { relations with his } \\
\text { wife and } \\
\text { choosing pious } \\
\text { friends }\end{array}$ & $\begin{array}{l}\text { No psychological } \\
\text { non-religious } \\
\text { recovery }\end{array}$ & $\begin{array}{l}\text { Entrepreneurs interpreted a } \\
\text { disaster with the paradigm that } \\
\text { God cleanses all haram property. }\end{array}$ \\
\hline $\mathrm{E}$ & $\begin{array}{l}\text { Friends provided help and } \\
\text { he/she worked as an } \\
\text { employee in a private } \\
\text { hospital and as freelance } \\
\text { tour guide. }\end{array}$ & $\begin{array}{l}\text { No social } \\
\text { recovery }\end{array}$ & $\begin{array}{l}\text { His wife gave moral } \\
\text { support. }\end{array}$ & $\begin{array}{l}\text { His recovery was by getting } \\
\text { closer and surrendering to God. }\end{array}$ \\
\hline $\mathrm{F}$ & $\begin{array}{l}\text { Her husband provided } \\
\text { loans to start a new } \\
\text { business }\end{array}$ & $\begin{array}{l}\text { No social } \\
\text { recovery }\end{array}$ & $\begin{array}{l}\text { Support from her } \\
\text { parents and her } \\
\text { husband }\end{array}$ & Doing more charity \\
\hline
\end{tabular}

businesses. Three of the six recovery forms were given loans from other parties, such as loans from family or other parties. Singh et al. [7] also indicated the same thing. Finding a job is a solution to the lost income due to business failure. Also, entrepreneurs sold assets and the spouse and sharing stories with friends. All informants in this study employed psychologicalreligious to recover from the psychological loss. They drew closer to God, asking Allah for guidance. They prayed a lot to recover from this failure. This study confirms Singh's [31] research that spirituality impacts 
psychology recovery from business failure. Table 5 shows quotes regarding losses' recovery for entrepreneurs re-entering from business failures.

\section{CONCLUSION}

This study examines the impact of entrepreneurial failure and how entrepreneurs recover and get back up to start their business again. Business failure has caused economic, social and psychological losses. The results of this study have proven that unsuccessful entrepreneurs alms. need economic, social and psychological recovery from losses. In this study, the economic recovery from business failures was through family support and loans, bank loans, gifts from friends, and working as employees in other businesses. Meanwhile, the impact recovery process was by establishing new relationships with other suppliers by instilling trust. Besides, support from family and friends was the psychological recovery. Religiously, recovery from business failure was done with more worship and giving

Table 5. Quotes Regarding Recovery of Losses for Entrepreneurs Re-entering from Business Failures

\begin{tabular}{|c|c|c|}
\hline Problem & Recovery & Example Supportive quotes \\
\hline $\begin{array}{l}\text { Economy } \\
\text { Financial Pressure }\end{array}$ & $\begin{array}{l}\text { Working for other parties } \\
\text { Getting a loan from another party }\end{array}$ & $\begin{array}{l}\text {.. I work to pay debts .. to get up and for other businesses ... } \\
\text { "The vendor is good ... giving the opportunity to pay in instalments" ... " the vendor } \\
\text { considers paid off a portion of the loan. " } \\
\text { Someone helped me ... asked me to state the amount of my loan and which bank I } \\
\text { borrowed from ... he paid off all my bank loans ... and allowed me to repay as much } \\
\text { as I could ... } \\
\text {.. when I was not working, there was no income .. but it was amazing .. here and } \\
\text { there friends, I do not know where the help came from... } \\
\text {...my husband gave a help for the start of a new business }\end{array}$ \\
\hline Social & Looking for better friends & $\begin{array}{l}\text {.. hopefully, it will be replaced by Allah with better friends. Friendships will be more } \\
\text { lasting if they are based on religion. Currently, we have more friends... more able to } \\
\text { support each other... more strengthening. }\end{array}$ \\
\hline $\begin{array}{l}\text { Non-religious } \\
\text { psychology }\end{array}$ & Support from friends & "Friends give support ... I get support from friends who have the same fate... \\
\hline $\begin{array}{l}\text { Religious } \\
\text { psychology }\end{array}$ & Come back to God & $\begin{array}{l}\text {... Relying everything on Allah SWT when there is a shock, there is no need to be sad } \\
\ldots \text { the wife reinforces that fortune has been arranged, there is no need to worry } \\
\ldots \text { indeed, he strengthened it with worship and understanding of religion }\end{array}$ \\
\hline Problem & Recovery & Example Supportive quotes \\
\hline $\begin{array}{l}\text { Economy } \\
\text { Financial Pressure }\end{array}$ & $\begin{array}{l}\text { Working for other parties } \\
\text { Getting a loan from another party }\end{array}$ & $\begin{array}{l}\text {.. I work to pay debts .. to get up and for other businesses ... } \\
\text { "The vendor is good ... giving the opportunity to pay in instalments" ... " the vendor } \\
\text { considers paid off a portion of the loan. " } \\
\text { Someone helped me ... asked me to state the amount of my loan and which bank I } \\
\text { borrowed from ... he paid off all my bank loans ... and allowed me to repay as much } \\
\text { as I could ... } \\
\text {.. when I was not working, there was no income .. but it was amazing .. here and } \\
\text { there friends, I do not know where the help came from... } \\
\text {...my husband gave a help for the start of a new business }\end{array}$ \\
\hline
\end{tabular}


Figure 2. The Coding Regarding The Recovery of Losses for Entrepreneurs Re-entering from Business Failures.

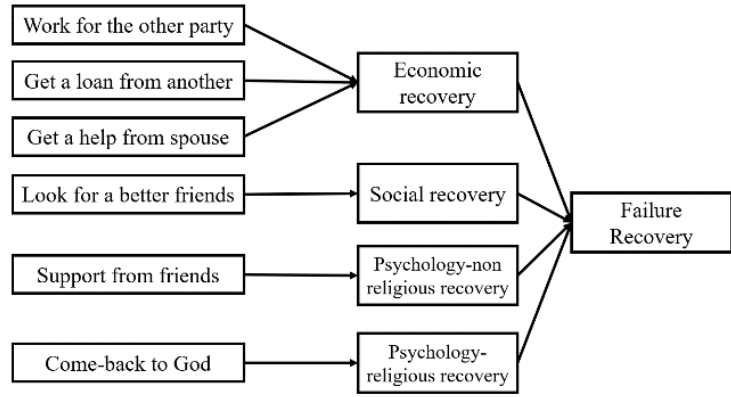

\section{ACKNOWLEDGMENTS}

The authors would like to thank six entrepreneurs who participated in taking their time to interview for this study. We also express our gratitude to the Institute for Research, Publication, and Community Service of the Universitas Muhammadiyah Yogyakarta for funding research through a research grant program.

\section{REFERENCES}

[1] Shepherd D A, Wiklund J and Haynie J M 2009 Moving Forward: Balancing the Financial and Emotional Costs of Business Failure Journal of Business Venturing 24 134-48

[2] Cope J 2011 Entrepreneurial Learning from Failure: An Interpretative Phenomenological Analysis Journal of Business Venturing 26 604-23

[3] Huy Q N 2002 Emotional Balancing of Organizational Continuity and Radical Change: The Contribution of Middle Managers Administrative Science Quarterly 4731

[4] Shepherd D A 2003 Learning from Business Failure: Propositions of Grief Recovery for the SelfEmployed Academy of Management Review 28 318-328

[5] Shepherd D A and Cardon M S 2009 Negative Emotional Reactions to Project Failure and the SelfCompassion to Learn from the Experience Journal of Management Studies 46 923-49

[6] Ucbasaran D, Shepherd D A, Lockett A and Lyon S J 2013 Life After Business Failure: The Process and Consequences of Business Failure for Entrepreneurs Journal of Management 39 163-202

[7] Singh S, Corner P and Pavlovich K 2007 Coping with Entrepreneurial Failure Journal of Management \& Organization 13 331-44
[8] Shepherd D A and Patzelt H 2017 Trailblazing in Entrepreneurship (Cham: Springer International Publishing)

[9] Shepherd D A and Haynie J M 2011 Venture failure, stigma, and impression management: A selfverification, self-determination view Strat.Entrepreneurship J. 5 178-97

[10] Pargament K I, Smith B W, Koenig H G and Perez L 1998 Patterns of Positive and Negative Religious Coping with Major Life Stressors Journal for the Scientific Study of Religion 37710

[11] Amankwah-Amoah J and Wang X 2019 Business Failures around the World: Emerging Trends and New Research Agenda Journal of Business Research 98 367-9

[12] Kücher A and Feldbauer-Durstmüller B 2019 Organizational Failure and Decline - A Bibliometric Study of The Scientific Frontend Journal of Business Research 98 503-16

[13] Li H and Zhang Q 2016 A Literature Review of Learning from Failure and Prospects for Future Research 2016 International Conference on Management Science and Innovative Education (Atlantis Press)

[14] Cochran A B 1981 Small Business Mortality Rates: A Review of The Literature Journal of Small Business Management (pre-1986); Milwaukee 1950

[15] Gimeno J, Folta T B, Cooper A C and Woo C Y 1997 Survival of the Fittest? Entrepreneurial Human Capital and the Persistence of Underperforming Firms Administrative Science Quarterly 42 750-83

[16] Watson J and Everett J E 1996 Do Small Businesses Have High Failure Rates? Journal of Small Business Management; Milwaukee 34 45-62

[17] Fredland J E and Morris C E 1976 A Cross Section Analysis of Small Business Failure American Journal of Small Business 1 7-18

[18] Headd B 2003 Redefining Business Success: Distinguishing Between Closure and Failure Small Business Economics 21: 51-61 11

[19] Stokes D and Blackburn R 2002 Learning the Hard Way: The Lessons of Owner-Managers who have Closed Their Businesses. Journal of Small Business and Enterprise Development 9 17-27

[20] Hall G and Young B 1991 Factors Associated with Insolvency amongst Small Firms International Small Business Journal 9 54-63

[21] Cannon M D and Edmondson A C 2001 Confronting Failure: Antecedents and Consequences of Shared Beliefs About Failure in 
Organizational Work Groups Journal of

Organizational Behavior 22 161-77

[22] Cannon M D and Edmondson A C 2005 Failing to Learn and Learning to Fail (Intelligently) Long Range Planning 38 299-319

[23] Mcgrath R G 1999 Falling Forward: Real Options Reasoning and Entrepreneurial Failure Academy of Management Review 24 13-30

[24] Watson J and Everett J 1993 Defining Small Business Failure International Small Business Journal 11 35-48

[25] Coelho P R and McClure J E 2005 Learning from failure Mid-American Journal of Business 20 13-20

[26] Jenkins, Wiklund J and Brundin E 2014 Individual responses to firm failure: Appraisals, grief, and the influence of prior failure experience Journal of Business Venturing 29 17-33

[27] Pargament K I, Ensing D S, Falgout K, Olsen H, Reilly B, Van Haitsma K and Warren R 1990 God help me: (I): Religious coping efforts as predictors of the outcomes to significant negative life events American Journal of Community Psychology 18 793-824

[28] Miles M B, Huberman A M and Saldana J 2014 Qualitative Data Analysis (SAGE)

[29] Yin R K 2003 Case Study Research: Design and Methods: (Applied Social Research Methods, Volume 5): 005 (Thousand Oaks, Calif: SAGE Publications, Inc)

[30] Westhead P 2005 Experience and Cognition: Do Novice, Serial and Portfolio Entrepreneurs Differ? International Small Business Journal 23 72-98

[31] Singh S, Corner P D and Pavlovich K 2016 Spirituality and Entrepreneurial Failure Journal of Management, Spirituality \& Religion 13 24-49

[32] Munawaroh, M., \& Rimiyati, H., 2016, Evaluation Of Women Business Community Development Through The Revolving Loan Fund Recipients From Upk Spp In Bantul Regency, Yogyakarta Indonesia. Proceedings of ICMSDM, Taiwan. 